\title{
Kilka uwag o Internetowej Platformie Aukcyjnej umożliwiającej uzyskanie wsparcia w zakresie odnawialnych źródeł energii w kontekście podpisów elektronicznych
}

\section{Wprowadzenie}

Wytwarzanie energii elektrycznej, jako część sektora elektroenergetycznego, poddane jest bardzo silnej interwencji prawnej państwa, w doktrynie nazywanej regulacją sektorową ${ }^{1}$. Państwo poprzez realizację władzy ustawodawczej tworzy różnego rodzaju instrumenty prawne kreujące m.in. zasady podejmowania, prowadzenia oraz zakończenia działalności wytwórczej w elektroenergetyce. W związku z powyższym działania $\mathrm{w}$ tym sektorze nie są podporządkowane jedynie czystym zasadom ekonomii, a wytwórcy, prowadząc w tym zakresie działalność gospodarcza, muszą uwzględniać wysoki stopień ryzyka związanego z systematycznie wprowadzanymi i często zmieniającymi się regulacjami prawnymi. Jednakże interwencja w sektor elektroenergetyczny nie nosi jedynie znamion interwencjonizmu restrykcyjnego ${ }^{2}$, ograniczającego lub reglamentującego prowadzenie danej działalności gospodarczej w sektorze elektroenergetycznym. Najjaskrawszym przykładem w tym

${ }^{1}$ E. Kosiński, Regulacja sektorowa - stałość czy zmienność pojęcia?, w: Prawne instrumenty oddziaływania na gospodarke, pod red. A. Powałowskiego, Warszawa 2016, s. 97-120; T. Długosz, Funkcja regulacyjna, w: Publiczne prawo gospodarcze, seria System Prawa Administracyjnego, pod red. R. Hausera, Z. Niewiadomskiego, A. Wróbla, t. 8A, Warszawa 2013, s. 697-707.

${ }^{2}$ K. Strzyczkowski, Prawo gospodarcze publiczne, Warszawa 2011, s. 188-189; K. Horubski, Wspieranie gospodarki, w: Publiczne Prawo Gospodarcze..., s. 753-755. 
zakresie są instrumenty prawne stanowiące pomoc publiczną, zachęcające przedsiębiorców do prowadzenia danego rodzaju działalności gospodarczej. Jednym z najnowszych, a zarazem najdynamiczniej rozwijających się rodzajów pomocy publicznej w elektroenergetyce jest pomoc przyznawana na promowanie wytwarzania energii elektrycznej z odnawialnych źródeł energii (OZE). Na tej podstawie zarówno prawodawca europejski, jak i ustawodawca polski dostrzegli konieczność systemowego ${ }^{3}$ wspierania rozwoju OZE, dostrzegając w nich potencjał do zrównoważonego rozwoju gospodarki. Wsparcie to realizowane jest w szczególności poprzez prawne instrumenty stanowiące pomoc publicznąa ${ }^{4}$ która musi być zgodna z regułami konkurencji UE. Dany system finansowego wsparcia wytwarzania energii elektrycznej z OZE $\mathrm{w}$ danym państwie członkowskim musi zatem opierać się na indywidualnej notyfikacji przepisów Komisji Europejskiej albo na przepisach rozporządzenia Komisji (UE) nr 651/2014 z dnia 17 czerwca 2014 r. uznającego niektóre rodzaje pomocy za zgodne z rynkiem wewnętrznym w zastosowaniu art. 107 i 108 Traktatu $^{5}$, zawierających generalne (blokowe) wyłączenia spod zakazu udzielania niedozwolonej pomocy publicznej.

\section{Prawne podstawy funkcjonowania systemu IPA}

W związku z powyższym wprowadzony w Polsce, Ustawą z dnia 20 lutego 2015 r. o odnawialnych źródłach energii ${ }^{6}$, system aukcji OZE

${ }^{3}$ Na konieczność zastosowania przemyślanej strategii publicznego wsparcia inwestycji w zakresie OZE wskazują T. Henzelmann, P Hoff, Zielone finansowanie i nowe "zielone złoto", w: Zielony wzrost, zielony zysk. Jak zielona rewolucja stymuluje gospodarke, pod red. R. Bergera, tłum. A. Kozłowska, Warszawa 2014, s. 280-285.

${ }^{4}$ Szerzej zob. D. Kobiałko, Analiza ustawy o odnawialnych źródłach energii z 20 lutego 2015 roku w świetle przepisów unijnych dotyczących pomocy publicznej, „Przegląd Prawniczy Europejskiego Stowarzyszenia Studentów Prawa ELSA Poland" 2015, z. 3, s. 167-183; W. Szopiński, Czy systemy wsparcia dla energii z odnawialnych źródet przewidziane w projekcie ustawy o odnawialnych źródłach energii można uznać za pomoc publiczną?, „Przegląd Prawniczy Europejskiego Stowarzyszenia Studentów Prawa ELSA Poland" 2015, z. 3, s. 153-166.

${ }^{5}$ Dz.Urz. UE C 187 z 17 VI 2014 r., s. 1.

${ }^{6}$ Dz.U. 2015, poz. 478, dalej „u.o.z.e.”.

${ }^{7}$ A. Bohdan, M. Przybylska, Podstawy prawne OZE (odnawialnych źródeł energii) i gospodarki odpadami w Polsce, Warszawa 2015, s. 55-56; T. Długosz, Aukcja na sprzedaż energii elektrycznej wytwarzanej z odnawialnych źródet energii wytworzonej w instalacjach odnawialnego źródła energii - nowy środek wspierajacy wybrany sektor gospodarki, w: Prawne instrumenty..., s. 431-439. 
implementuje przepisy dyrektywy Parlamentu Europejskiego i Rady 2009/28/WE z dnia 23 kwietnia 2009 r. w sprawie promowania stosowania energii ze źródeł odnawialnych zmieniającej i w następstwie uchylającej dyrektywy 2001/77/WE oraz 2003/30/WE ${ }^{8}$, a także wprowadza zestaw rozwiązań rekomendowanych w Komunikacie Komisji Wytyczne w sprawie pomocy państwa na ochronę środowiska i cele związane z energią w latach 2014-2020 . Celem wprowadzenia systemu aukcji OZE jest wytworzenie w sposób najbardziej efektywny kosztowo określonego wolumenu energii ze źródeł odnawialnych, w ramach nałożonych na Polskę zobowiązań wynikających z polityki klimatyczno-energetycznej UE. Oznacza to, że w drodze konkurencyjnych aukcji OZE, organizowanych przez Prezesa Urzędu Regulacji Energetyki (dalej: Prezes URE), zostaną wyłonieni wytwórcy energii z instalacji OZE, którzy będą objęci przewidzianym przez ustawodawcę systemem wsparcia. Podstawowym kryterium wygrania aukcji, w ramach przewidzianych przez Radę Ministrów maksymalnych limitów ${ }^{10}$, jest cena sprzedaży, po której gotowi są oni wytwarzać tę energię z instalacji OZE w 15-letnim okresie wsparcia.

W tym miejscu należy jednak postawić pytanie, dlaczego system wsparcia wytwarzania energii elektrycznej z OZE w formie aukcji jest tak innowacyjnym instrumentem prawnym wspierającym wizję rozwoju e-administracji? Odpowiadając na nie, w szczególności należy wskazać na fakt, że system aukcji OZE jest pierwszym polskim instrumentem prawnym umożliwiającym uzyskanie wsparcia na wytwarzanie energii z OZE jedynie za pośrednictwem specjalnej platformy dostępnej wyłącznie w środowisku internetowym. Oznacza to, że każdy wytwórca ${ }^{11}$, a zwłaszcza przedsiębiorca planujący wytwarzanie energii elektrycznej z OZE, dotowanej zgodnie z przepisami u.o.z.e., musi wziąć udział w aukcji OZE odbywającej się jedynie w przestrzeni elektronicznej. Podstawa prawna takiego ukształtowania nowego systemu wsparcia OZE wskazana jest $\mathrm{w}$ art. 78 ust. 6 u.o.z.e., który expressis verbis wskazuje, że aukcje prowadzi się w postaci elektronicznej za pośrednictwem

${ }^{8}$ Dz.Urz. UE L 140 z 23 IV 2009 r., s. 16.

${ }^{9}$ Dz.Urz. UE C 200 z 28 VI 2014 r., s. 1.

${ }^{10}$ Zob. projekt rozporządzenia Rady Ministrów w sprawie maksymalnej ilości i wartości energii elektrycznej z odnawialnych źródeł energii, która może być sprzedana w drodze aukcji w 2016 r.

${ }^{11}$ Szerzej na temat zakresu pojęcia wytwórcy OZE zob. E. Kosiński, M. Trupkiewicz, Gmina jako podmiot systemu wspierania wytwarzania energii elektrycznej z odnawialnych źródeł energii, „Ruch Prawniczy, Ekonomiczny i Socjologiczny” 2016, z. 3, s. 102-105. 
internetowej platformy aukcyjnej. Organem właściwym w sprawach ogłoszenia, organizacji oraz przeprowadzenia aukcji OZE jest Prezes URE, który zgodnie z regułami prawa zamówień publicznych stworzył i udostępnił Internetową Platformę Aukcyjną (IPA). Wytwórcy energii z OZE, chcąc wziąć udział w nowym systemie wsparcia, obligatoryjnie muszą posługiwać się systemem IPA, wyłącznie za pośrednictwem którego mogą załatwić sprawę administracyjną związaną z udzieleniem pomocy publicznej na wytwarzanie energii elektrycznej z instalacji OZE.

W tym zakresie należy wskazać, że na podstawie art. 78 ust. 8 u.o.z.e. Prezes URE ustalił Regulamin aukcji na sprzedaż energii elektrycznej wytwarzanej w instalacjach odnawialnego źródła energii (dalej: Regulamin Aukcji), który został opublikowany w Biuletynie Informacji Publicznej Urzędu Regulacji Energetyki ${ }^{12}$. Regulamin Aukcji określa w szczególności przebieg i sposób rozstrzygania aukcji OZE, warunki przetwarzania danych dotyczących wytwórców zamierzających przystąpić do aukcji OZE, wymagania techniczne dotyczące dostępu do systemu IPA, sposoby zapewnienia bezpieczeństwa i prawidłowości przebiegu aukcji OZE oraz warunki zawieszenia dostępu do systemu IPA. W związku z powyższym Regulamin Aukcji zawiera szczegółowe zasady dotyczące praktycznych aspektów przeprowadzania aukcji OZE. Administrator systemu IPA, którym zgodnie z $\$ 2$ pkt 1 Regulaminu Aukcji jest pracownik URE uprawniony do obsługi IPA. Prezes URE opracował również dokument "Instrukcja użytkownika Internetowej Platformy Aukcyjnej"13 (dalej: Instrukcja). Dokument ten określa szczegółowe zasady korzystania $z$ aktualnej wersji oprogramowania IPA, w tym m.in. zasady tworzenia loginów, wymagania dotyczące haseł bezpieczeństwa do kont wytwórców, limity wielkości załączanych plików, opisy pól poszczególnych formularzy, etykiety pól, kolejność wypełniania pól poszczególnych formularzy, grafikę formularzy, lokalizację dostępnych funkcji oraz zasady korzystania z funkcji CAPTCHA. Przedmiotowa instrukcja użytkownika IPA odzwierciedla każdorazowo najbardziej aktualną wersję oprogramowania IPA, którą Prezes URE publikuje na stronie internetowej URE (http://www.ure.gov.pl/). Uwzględniając zatem innowacyjny charakter tego postępowania, należy prześledzić poszczególne funkcjonalności systemu IPA wraz ze szczegółową analizą

12 https://www.ure.gov.pl/pl/rynki-energii/energia-elektryczna/aukcje-oze/dokumenty/6548,Regulamin-aukcji.html (dostęp: 25 V 2017).

${ }^{13}$ https://www.ure.gov.pl/pl/rynki-energii/energia-elektryczna/aukcje-oze/dokumenty/6541,Instrukcja-uzytkowania-IPA.html (dostęp: 25 V 2017). 
praktycznych aspektów jego obsługi przez danych wytwórców energii z OZE zamierzających przystąpić do aukcji OZE.

Po pierwsze, należy wskazać, że dostęp do systemu IPA będzie możliwy jedynie za pośrednictwem strony internetowej Urzędu Regulacji Energetyki, przy wykorzystaniu klasycznych przeglądarek internetowych. Pierwszym etapem, przed którym stanie wytwórca energii z instalacji OZE, będzie konieczność przejścia procedury rejestracji konta użytkownika, które stanowić będzie indywidualny profil w systemie IPA. Należy podkreślić, że za pośrednictwem owego indywidualnego profilu będzie można korzystać z poszczególnych modułów aplikacyjnych udostępnianych $\mathrm{w}$ systemie IPA $\mathrm{w}$ odniesieniu do wszystkich instalacji OZE zgłaszanych do aukcji OZE, którymi "dysponuje” dany wytwórca. Stworzenie profilu wymaga przeprowadzenia rejestracji wraz z podaniem indywidualnego loginu i hasła, których szczegółowe wymagania określił Prezes URE w Regulaminie Aukcji oraz Instrukcji. W tym zakresie ważne jest, że po zarejestrowaniu konta wytwórca nie ma możliwości zmiany loginu, dlatego dany wytwórca indywidualizowany przez system za pomocą wprowadzanego numeru NIP oraz rachunku bankowego nie będzie miał możliwości założenia drugiego konta użytkownika. Po utworzeniu własnego profilu potencjalni uczestnicy aukcji będą mogli zalogować się i uzyskać dostęp do pozostałych modułów aplikacyjnych dostępnych w systemie IPA. Po utworzeniu indywidualnego profilu wytwórcy w systemie IPA należy przeprowadzić odrębne postępowania prekwalifikacyjne dla wszystkich instalacji OZE, które dany wytwórca ma zamiar zgłosić do aukcji OZE.

\section{Postępowania prekwalifikacyjne w systemie IPA}

Kolejnym etapem umożliwiającym wzięcie udziału w aukcji OZE będzie prawidłowe przejście postępowań prekwalifikacyjnych. $\mathrm{W}$ art. 75 ust. 1 u.o.z.e. ustawodawca wskazuje, że wytwórca, który zamierza przystąpić do aukcji, podlega procedurze oceny formalnej przygotowania do wytwarzania energii elektrycznej w danej instalacji OZE. Podstawowym celem ustawodawcy w tym zakresie była zatem chęć przeprowadzenia swego rodzaju audytu prawnego poszczególnych projektów inwestycyjnych w instalacje OZE, których właściciele chcą wystartować $\mathrm{w}$ organizowanej $\mathrm{w}$ danym roku aukcji. Skuteczne przejście procedury prekwalifikacyjnej ma zapewnić bezzwłoczne przystąpienie do realizacji 
inwestycji zaraz po ewentualnym wygraniu aukcji OZE tak, aby w określonym w art. 79 ust. 3 pkt 8 lit. a u.o.z.e. terminie projektowana instalacja OZE mogła zostać zrealizowana, a w konsekwencji po raz pierwszy wytworzyć energię elektryczną.

Postępowania prekwalifikacyjne prowadzone są w systemie IPA oddzielnie dla wytwórców zamierzających wybudować nową instalację OZE oraz dla wytwórców, których instalacje zostały już wybudowane przed dniem wejścia w życie rozdziału 4 u.o.z.e., tj. przed 1 lipca 2016 r. W przypadku istniejących już instalacji OZE, które wytworzyły energię przed wskazaną powyżej data, zastosowanie znajdują przepisy art. 71 u.o.z.e. wskazujące na konieczność złożenia przez wytwórcę jedynie deklaracji o przystąpieniu do aukcji OZE ${ }^{14}$. Ponieważ postępowania tego rodzaju odnoszą się do instalacji już wybudowanych, mają one znacznie mniej skomplikowany charakter niż postępowania prekwalifikacyjne dotyczące instalacji, które zostaną dopiero wybudowane po wygraniu aukcji OZE ${ }^{15}$. Postępowania polegające na złożeniu deklaracji odbywają się w środowisku IPA poprzez wypełnienie stosownego formularza wskazującego lokalizację instalacji OZE, jej parametry techniczne, numer DKN nadany przez Prezesa URE albo wpisu do właściwego rejestru wytwórców w małej instalacji oraz złożenie stosownych oświadczeń. Uproszczenie tego etapu poprzedzającego aukcje OZE dla wytwórców dysponujących już instalacjami OZE jest uzasadnione z prakseologicznego punktu widzenia, gdyż instalacja taka została już wybudowana, a w związku z tym nie ma zagrożenia niewytworzenia energii elektrycznej w terminie przewidzianym przez przepisy u.o.z.e. Natomiast w stosunku do nowych instalacji OZE konieczne będzie przejście znacznie bardziej wnikliwych i skomplikowanych postępowań inicjowanych poprzez złożenie w systemie IPA wniosku o wydanie zaświadczenia o dopuszczeniu do udziału w aukcji OZE, dla którego właściwe będą przepisy wskazane $\mathrm{w}$ art. 75 ust. $3-5$ u.o.z.e. ${ }^{16}$ Użytkownik systemu IPA, chcąc "uwierzytelnić" zgłaszany przez siebie projekt inwestycji w instalację OZE, musi załączyć do wniosku odpo-

${ }^{14}$ Zob. J. Pokrzywniak, Komentarz do art. 71, w: Ustawa o odnawialnych źródłach energii. Komentarz, pod red. J. Baehra, P. Lissonia, J. Pokrzywniaka, M. Szambelańczyka, Warszawa 2016, s. 193-200.

${ }^{15}$ Zob. M. Trupkiewicz, Postępowania prekwalifikacyjne jako pierwszy etap udziału w aukcjach OZE, "Studia Prawa Publicznego" 2017, nr 1(17), s. 101-122.

${ }^{16}$ Zob. J. Pokrzywniak, Komentarz do art. 75, w: Ustawa o odnawialnych źródłach..., s. $214-224$. 
wiednie dokumenty w elektronicznym formacie PDF. Zgodnie z art. 75 ust. 5 u.o.z.e. dokumentami wymaganymi od nowo projektowanych instalacji OZE są potwierdzone za zgodnością z oryginałem właściwe dokumenty: potwierdzenie dopuszczalności inwestycji w danej lokalizacji ${ }^{17}$, prawomocne pozwolenie na budowę, harmonogram rzeczowy i finansowy oraz, w zależności od stadium inwestycji, umowa przyłączeniowa albo warunki przyłączenia projektowanej instalacji OZE do sieci elektroenergetycznej jednego z operatorów, a w przypadku inwestycji w morskie farmy wiatrowe dodatkowo także prawomocna decyzja o środowiskowych uwarunkowaniach. Interfejs systemu IPA pozwala również na złożenie przez danego użytkownika odpowiednich oświadczeń wskazanych $\mathrm{w}$ art. 71 ust. 3 oraz w art. 75 ust. 4 pkt 4 u.o.z.e., które stanowią część wypełnianego formularza. Przykładowo, wytwórca energii elektrycznej z biogazu rolniczego wskazuje, że świadomy odpowiedzialności karnej za złożenie fałszywego oświadczenia oświadcza, że do wytworzenia energii elektrycznej w swojej instalacji OZE nie będzie wykorzystywał substratów innych niż te wymienione $\mathrm{w}$ art. 2 pkt 2 u.o.z.e., a więc substratów umożliwiających wytworzenie biogazu rolniczego. Zgodnie z art. 75 ust. 4 pkt 4 u.o.z.e. klauzula ta zastępuje pouczenie organu o odpowiedzialności karnej za składanie fałszywych zeznań.

Niemniej, jak właściwie zauważy wnikliwy czytelnik, najważniejszą częścią całego postępowania prekwalifikacyjnego będzie prawidłowe podpisanie wniosku albo deklaracji oraz dołączonych do nich oświadczeń skutkujących prawidłowym wszczęciem postępowania administracyjnego na żądanie strony, o czym mowa w art. 61 \& 1 Ustawy z dnia 14 czerwca 1960 r. Kodeks postępowania administracyjnego ${ }^{18}$. Analiza przepisów u.o.z.e. pozwala dojść do wniosku, że w przypadku postępowań prekwalifikacyjnych ustawodawca wyjątkowo dopuścił możliwość „klasycznego" przebiegu procedury administracyjnej opartej na obiegu pisemnych dokumentów między wytwórcą a Prezesem URE. Oznacza to, że wytwórca może wszcząć owo postępowanie dzięki wystąpieniu ze stosownym pismem do Prezesa URE. W tym zakresie dyskusyjny

${ }^{17}$ Chodzi zatem o jeden z następujących dokumentów: wypis i wyrys z miejscowego planu zagospodarowania przestrzennego albo decyzja o warunkach zabudowy i zagospodarowania terenu albo prawomocnego pozwolenia na wznoszenie i wykorzystywanie sztucznych wysp, konstrukcji i urządzeń w polskich obszarach morskich dla przedsięwzięć zlokalizowanych w wyłącznej strefie ekonomicznej.

18 Tekst jedn. Dz.U. 2016, poz. 23. 
wydaje się wydany przez Prezesa URE przepis $\S 7$ ust. 8 Regulaminu Aukcji. Zgodnie z jego treścią otrzymanie przez wytwórcę pisemnej wersji zaświadczenia o dopuszczeniu do aukcji OZE albo deklaracji nie zwalnia tych wytwórców z wymogu wysłania odpowiedniego wniosku o wydanie zaświadczenia o dopuszczeniu do aukcji OZE za pośrednictwem systemu IPA. De facto oznacza to, że wytwórca, który otrzymał odpowiedni dokument w formie papierowej, co powinno zakończyć całe postępowanie, i tak będzie zmuszony do ponownego wprowadzenia tak uzyskanego dokumentu do systemu IPA, a następnie uzyskania akceptacji jego treści w systemie elektronicznym, administrowanym przez Prezesa URE.

Niezależnie od wskazanych powyżej kontrowersji dany wytwórca może też skorzystać z opisanych powyżej udogodnień systemu IPA i od razu zainicjować owo postępowanie w środowisku internetowym. Jeżeli wytwórca zdecyduje się na to drugie rozwiązanie, będzie musiał podpisać składany przez siebie wniosek przy wykorzystaniu podpisu potwierdzonego profilem zaufanym ePUAP, o którym mowa $\mathrm{w}$ art. 3 pkt 15 Ustawy z dnia 17 lutego 2005 r. o informatyzacji działalności podmiotów realizujących zadania publiczne ${ }^{19}$, albo przy wykorzystaniu kwalifikowanego podpisu elektronicznego, o którym mowa w art. 3 pkt 12 rozporządzenia Parlamentu Europejskiego i Rady (UE) 910/2014 z dnia 23 lipca 2014 r. w sprawie identyfikacji elektronicznej i usług zaufania w odniesieniu do transakcji elektronicznych na rynku wewnętrznym oraz uchylającego dyrektywę 1999/93/WE20 (dalej „rozporządzenie 910/2014"). Podpisany tak wniosek albo deklarację można wysłać za pośrednictwem systemu IPA i w ten sposób skutecznie zainicjować postępowanie o wydanie omawianego zaświadczenia.

Informatyczny system IPA zawiera również widoczny statusu każdego ze złożonych wniosków prekwalifikacyjnych, co umożliwia wytwórcy uzyskanie bezpośredniej informacji zwrotnej dotyczącej konieczności uzupełnienia bądź podpisania albo odrzucenia wniosku lub deklaracji. Wytwórca otrzyma również dodatkową informację o akceptacji wniosku lub jego odrzuceniu $w$ formie komunikatu dostępnego w systemie IPA oraz pocztą elektroniczna, na podany $\mathrm{w}$ formularzu rejestracyjnym adres e-mail. Po skutecznej realizacji postępowania prekwalifikacyjnego dana instalacja OZE nie tylko będzie nadal aktywna w systemie IPA, ale

\footnotetext{
${ }^{19}$ Tekst jedn. Dz.U. 2014, poz. 1114, dalej „u.i.d.”.

${ }^{20}$ Dz.Urz. UE L 257 z 28 VIII 2014 r., s. 73.
} 
wytwórca będzie mógł też wygenerować odpowiedni dokument elektroniczny potwierdzający uzyskanie zaświadczenia oraz dopuszczenie do udziału w aukcji OZE.

\section{Złożenie oferty w systemie IPA}

Wytwórcy, który uzyska możliwość wzięcia udziału w aukcji OZE w terminie jej przeprowadzania, system IPA automatycznie uaktywni kolejny ze swych modułów, który umożliwia bezpośrednie złożenie oferty w aukcji OZE. Oferta będzie mogła być złożona jedynie dla instalacji OZE, w odniesieniu do której pozytywnie rozstrzygnięto prowadzone postępowanie prekwalifikacyjne. $\mathrm{W}$ module tym dany wytwórca ma możliwość podglądu szczegółowych informacji na temat terminu oraz rodzaju przeprowadzania poszczególnych aukcji OZE, a także o godzinie otwarcia oraz zamknięcia danej aukcji OZE. W tym miejscu należy również wskazać, że po uwzględnieniu przepisów u.o.z.e. Prezes URE będzie miał możliwość zorganizowania w systemie IPA aż 56 rodzajów odrębnych aukcji OZE, w których będą mogli wziąć udział wytwórcy dysponujący instalacjami OZE chrakteryzującymi się odpowiednio wymaganymi przez u.o.z.e. parametrami technicznymi ${ }^{21}$.

Wytwórca będący uczestnikiem aukcji zgodnie z art. 79 ust. 1 u.o.z.e. przekazuje ofertę za pomocą formularza zamieszczonego na platformie IPA. Uczestnik może złożyć tylko jedną ofertę, którą może następnie zmienić poprzez wycofanie starej oraz wprowadzenie nowej oferty do systemu IPA. Jednakże oferta złożona na godzinę przed zamknięciem sesji aukcji wiąże danego uczestnika do końca danej sesji aukcji OZE i nie może zostać wycofana. Składana oferta powinna zawierać dane wskazane w art. 79 ust. 3 pkt 1-9 u.o.z.e., a w szczególności określać łączną ilość energii elektrycznej oferowanej na sprzedaż w maksymalnym 15-letnim okresie wsparcia, z podziałem na poszczególne lata prowadzonej działalności gospodarczej. Drugim ważnym elementem oferty jest konieczność określenia oferowanej ceny aukcyjnej za dostarczaną

${ }^{21}$ System IPA będzie umożliwiał przeprowadzenie odrębnych aukcji w ramach pięciu, a od 1 lipca 2017 r. aż siedmiu tzw. koszyków technologicznych wymienionych w art. 73 ust. 3a u.o.z.e. Dodatkowo w ramach każdego z tzw. koszyków technologicznych aukcje będą przeprowadzane odrębnie dla instalacji do oraz powyżej 1 MW. Przykładowo, można wskazać, że odrębne aukcje będą prowadzone dla biogazowni rolniczych (jeden z tzw. koszyków technologicznych) o mocy zainstalowanej elektrycznej do oraz powyżej $1 \mathrm{MW}$. 
energię, która to cena będzie podstawowym kryterium rozstrzygania poszczególnych aukcji OZE. W tym zakresie należy wskazać, że oferta aukcyjna podlega odrzuceniu, jeżeli cena sprzedaży oferowanej energii, powiększona o inną jednostkową pomoc publiczną (dotacje, preferencyjne pożyczki, ulgi podatkowe itp.) uzyskaną przez wytwórcę na daną instalację OZE przekracza poziom ceny referencyjnej (ceny maksymalnej), określonej przez ministra właściwego do spraw energii na podstawie art. 77 ust. 1 u.o.z.e. ${ }^{22}$ Co do samego przebiegu aukcji OZE należy jeszcze wskazać, że zgodnie z art. 79 ust. 6 u.o.z.e. oferta każdego uczestnika jest niedostępna dla pozostałych uczestników aukcji OZE. Oznacza to, że aukcje OZE prowadzone są w sposób statyczny w tym sensie, że konkurujący ze sobą przedsiębiorcy nie wiedzą, jaką ofertę złożyli ich konkurenci, a w związku z tym nie mogą aktywnie uczestniczyć w aukcji OZE. Z łatwością bowiem można sobie wyobrazić że wytwórcy, wykorzystując internetowy system IPA, reagują w czasie rzeczywistym i składają kontroferty, poprawiając swoje szanse na uzyskanie wsparcia w ramach przewidzianego przez Radę Ministrów wolumenu energii, stanowiącego przedmiot aukcji OZE ${ }^{23}$. W tym aspekcie należy zatem wskazać, że nie wykorzystano w pełnym zakresie potencjału przeprowadzania aukcji OZE, w których to uczestniczące podmioty rywalizują między sobą jedynie na podstawie kryterium, jakim jest jak najniższa cena wytworzenia energii elektrycznej z OZE w jednym $z$ odrębnych rodzajów aukcji OZE, o których mowa w art. 73 ust. 3a $\mathrm{w}$ zw. $\mathrm{z}$ art. 73 ust. 4 u.o.z.e. Jeżeli bowiem z punktu widzenia interesu publicznego nie ma innych niż cenowe kryteriów wyboru danej oferty w ramach jednego z 56 rodzajów odrębnie organizowanych aukcji OZE, to wprowadzenie dynamicznego modelu przeprowadzania aukcji OZE pozwoliłoby zintensyfikować konkurencyjne działania wytwórców, rywalizujących o uzyskanie pomocy publicznej, która jest przecież finansowana z opłaty OZE, o której mowa w art. 95 ust. 1 u.o.z.e., pobieranej od odbiorców końcowych wraz z rachunkiem za energię elektryczną.

Poczynione powyżej uwagi skłaniają do postawienia tezy, że aukcje OZE ukształtowane przez przepisy u.o.z.e. bardziej przypominają klasyczny mechanizm przetargu, wykorzystywany zarówno jako jedna

${ }^{22}$ Szerzej zob. M. Trupkiewicz, M. Tarka, Sposób kalkulacji aukcyjnych cen energii z OZE, „Czysta Energia" 2016, nr 1, s. 16-18; A. Stawicki, Komentarz do art. 39, w: Ustawa o odnawialnych źródłach..., s. 98-108.

${ }^{23}$ Zob. rozporządzenia wydawane corocznie przez Radę Ministrów na podstawie art. 72 ust. 1 u.o.z.e. 
z form zawarcia umowy cywilnoprawnej, o czym mowa w art. $70^{1}$ Ustawy z dnia 23 kwietnia 1964 r. Kodeks cywilny ${ }^{24}$, jak i w postępowaniach o charakterze administracyjnym, w szczególności jako jedna z form rozstrzygnięcia postępowania $\mathrm{w}$ zakresie udzielenia ograniczonej liczby koncesji ${ }^{25}$, o którym mowa w art. 52 Ustawy z dnia 2 lipca $2004 \mathrm{r}$. o swobodzie działalności gospodarczej ${ }^{26}$. Niezależnie od dostrzeżonych podobieństw należy jednak podkreślić odrębność aukcji OZE, jako niezależnego instrumentu prawnego uregulowanego $\mathrm{w}$ przepisach u.o.z.e. i wykorzystywanego jedynie do wyłonienia wytwórców objętych systemem finansowego wsparcia prowadzonej działalności gospodarczej w zakresie OZE. Dogłębniej analizując charakter prowadzonego postępowania, należy wskazać, że złożenie oferty w danej aukcji OZE, w odróżnieniu od postępowań prekwalifikacyjnych, odbywa się jedynie w środowisku internetowym, za pośrednictwem systemu IPA. W związku z powyższym wytwórca, chcąc wziąć udział w aukcji OZE, nie może złożyć oferty aukcyjnej w tradycyjnej formie papierowej. Przesądza o tym chociażby dyspozycja art. 79 ust. 4 u.o.z.e., zgodnie z którą wytwórca skonstruowaną przez siebie ofertę aukcyjną pod rygorem nieważności opatruje kwalifikowanym podpisem elektronicznym albo podpisem potwierdzonym profilem zaufanym ePUAP. $\mathrm{W}$ związku z powyższym na tym etapie postępowania administracyjnego polegającego na udzieleniu pomocy publicznej na wytwarzanie energii elektrycznej z OZE ustawodawca jednoznacznie wskazuje, że jedynym sposobem złożenia oferty w aukcji OZE jest jej złożenie za pośrednictwem formularza udostępnionego w internetowym systemie IPA oraz opatrzenie jej jedną z dopuszczonych przez ustawodawcę form podpisu elektronicznego.

W tym miejscu należy pokrótce scharakteryzować obie formy umożliwiające poszczególnym wytwórcom podpisanie oferty składanej w internetowym środowisku systemu IPA oraz wskazać na ewentualne wady i zalety posługiwania się każdą z tych metod uwierzytelniania oferty aukcyjnej. Na tym etapie prowadzonych rozważań należy wskazać, że system elektronicznego uwierzytelniania składanych przez poszczególne podmioty oświadczeń, w tym również w ramach postępowań administracyjnych, obecnie podlega dostosowaniu do wspólnych europejskich

\footnotetext{
${ }^{24}$ Tekst jedn. Dz.U. 2017, poz. 459.

${ }^{25}$ A. Trela, Postepowanie w sprawie udzielenia ograniczonej liczby koncesji, "Ruch Prawniczy, Ekonomiczny i Socjologiczny" 2005, z. 4, s. 51-64.

${ }^{26}$ Tekst jedn. Dz.U. 2016, poz. 1829.
} 
reguł, ustalonych w tym zakresie przez bezpośrednio obowiązujące rozporządzenie 910/2014. Działania te, prowadzone w szczególności przez ministra właściwego do spraw informatyzacji, przyjęły swój normatywny wymiar w Ustawie z dnia 5 września 2016 r. o usługach zaufania oraz identyfikacji elektronicznej ${ }^{27}$. Ustawa ta w szczególności określa instytucjonalne ramy tworzonej krajowej infrastruktury zaufania, która determinuje zunifikowane w całej UE zasady działalności dostawców usług zaufania (trust services), a także wprowadza wiele doraźnych zmian w przepisach innych ustaw mających ułatwić korzystanie z podpisów elektronicznych. Cała reforma ma się zakończyć wraz $\mathrm{z}$ wejściem w życie wszystkich przepisów u.z.i.e., tj. w dniu 29 września 2018 r. Niemniej, ze względu na aktualny stan prawny, podkreślenia wymaga fakt, że zgodnie z art. $131 \mathrm{w}$ zw. z art. 132 ust. 1 u.z.i.e. dotychczasowo funkcjonujący w obrocie prawnym bezpieczny podpis elektroniczny weryfikowany za pomocą ważnego kwalifikowanego

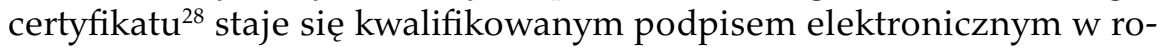
zumieniu rozporządzenia 910/2014, o ile potwierdzający je certyfikat nie zostanie unieważniony. W tym zakresie warto wskazać, że zgodnie z rozporządzeniem 910/2014 kwalifikowany podpis elektroniczny oznacza zaawansowany podpis elektroniczny, który po pierwsze, składany jest za pomocą kwalifikowanych urządzeń do składania podpisu elektronicznego, a po drugie, opiera się na kwalifikowanym certyfikacie podpisu elektronicznego. Tak więc usługa ta musi być świadczona przy wykorzystaniu urządzenia do składania podpisu elektronicznego (oprogramowanie lub sprzęt), spełniającego wymogi określone w załączniku II do rozporządzenia 910/2014, a także być potwierdzona stosowaniem odpowiedniego certyfikatu (dane służące walidacji podpisu elektronicznego danej osoby fizycznej), spełniającego wymogi załącznika I do przedmiotowego rozporządzenia. Dopiero tak wykonany kwalifikowany podpis elektroniczny, zgodnie z art. 25 ust. 2 rozporządzenia 910/2014, ma skutek prawny równoważny podpisowi własnoręcznemu, przy czym podpis taki powinien być uznawany we wszystkich pozostałych państwach członkowskich UE.

W związku z powyższym wytwórca chcący skutecznie złożyć ofertę w aukcji OZE będzie mógł skorzystać $z$ kwalifikowanego podpisu elektronicznego potwierdzonego kwalifikowanym certyfikatem podpisu

27 Dz.U. 2016, poz. 1579 (dalej „u.u.z.i.e.").

${ }^{28}$ Instrument prawny funkcjonujący dotychczas na podstawie uchylonej Ustawy z dnia 18 IX 2001 r. o podpisie elektronicznym (tekst jedn. Dz.U. 2013, poz. 262). 
elektronicznego wydawanym przez dostawcę usług zaufania w rozumieniu art. 3 pkt 19 rozporządzenia 910/2014. Niemniej tworzenie, weryfikacja i walidacja kwalifikowanego podpisu elektronicznego i związanego z nim certyfikatu stanowią usługę elektroniczna, którą - jeśli dane państwo członkowskie zdecyduje się ją przekazać przekazać prywatnym przedsiębiorcom - co do zasady będzie świadczona za wynagrodzeniem. Warto podkreślić, że w Polsce taka praktyka była już przyjęta na mocy poprzedniego stanu prawnego, w którym expressis verbis wskazywano, że świadczenie takiego rodzaju usług było działalnością gospodarczą. W związku z powyższym, uwzględniając brzmienie najnowszych przepisów prawa w zakresie kwalifikowanego podpisu elektronicznego, istnieje duże prawdopodobieństwo, że tak jak dotychczas usługa tego typu będzie świadczona za wynagrodzeniem, a zwiększenie administracyjnoprawnego nadzoru nad prowadzeniem tego typu działalności gospodarczej może również spowodować wzrost cen za tego typu usługi.

Drugą formą podpisu elektronicznego, za pomocą którego wytwórca energii elektrycznej w instalacji OZE może uwierzytelnić składaną przez siebie dyspozycję $\mathrm{w}$ systemie IPA, jest podpis potwierdzony profilem zaufanym ePUAP, o którym mowa w art. 3 pkt 15 u.i.d. Zanim jednak wytwórca będzie mógł wykorzystywać oraz składać podpis potwierdzony profilem zaufanym ePUAP, musi stać się użytkownikiem profilu ePUAP, który został wiarygodnie potwierdzony w jeden ze sposobów wskazanych $\mathrm{w}$ art. 20c u.i.d. W tym zakresie warto podkreślić, że szczegółowe zasady tworzenia profilu zaufanego ePUAP określa Rozporządzenie Ministra Cyfryzacji z dnia 5 października 2016 r. w sprawie profilu zaufanego elektronicznej platformy usług administracji publicznej ${ }^{29}$. Inicjując procedurę utworzenia profilu zaufanego ePUAP, należy zarejestrować swój profil w systemie elektronicznym dostępnym na rządowej stronie internetowej www.pz.gov.pl, wprowadzając do niego zestaw danych identyfikujących i opisujących użytkownika tego profilu, $w$ tym przede wszystkim login, imię i nazwisko, numer telefonu oraz numer PESEL. Następnie po wprowadzeniu wskazanych danych system automatycznie prześle na wskazany numer telefonu kod autoryzacyjny, potwierdzający chęć założenia profilu zaufanego ePUAP. Za pośrednictwem założonego konta użytkownik powinien złożyć elektroniczny wniosek o potwierdzenie profilu zaufanego ePUAP, przy czym należy zaznaczyć, że od 1 stycznia 2017 r. wniosek taki będzie można złożyć również w formie

${ }^{29}$ Dz.U. 2016, poz. 1633. 
tradycyjnego wniosku papierowego, w odpowiednim punkcie potwierdzającym. W terminie 14 dni od złożenia owego wniosku, niezależnie od formy pisemnej czy elektronicznej, użytkownik profilu powinien udać się do wybranego przez siebie punktu potwierdzającego, w którym upoważniony urzędnik na podstawie dowodu osobistego lub paszportu stwierdzi tożsamość wnioskodawcy, potwierdzi prawidłowość wprowadzonych do systemu ePUAP danych oraz nada uprawnienia umożliwiające wykorzystanie podpisu potwierdzonego profilem zaufanym ePUAP. Zgodność wskazanych powyżej danych ze stanem faktycznym swoimi podpisami potwierdzają zarówno upoważniony urzędnik, jak i sam wnioskodawca. W tym zakresie należy wskazać, że funkcję punktu potwierdzającego z mocy prawa pełnią: konsul, naczelnik urzędu skarbowego, wojewoda oraz Zakład Ubezpieczeń Społecznych. Niemniej na podstawie odrębnych przepisów, za zgodą ministra właściwego do spraw informatyzacji, funkcję punktu potwierdzającego może pełnić także inny podmiot administracji publicznej, w tym również jednostki samorządu terytorialnego, a także m.in. bank krajowy oraz operator pocztowy, o których mowa we właściwych przepisach prawa.

Co więcej, nowelizacja owych przepisów, która weszła w życie 7 października 2016 r., umożliwia samodzielne potwierdzanie profilu zaufanego przez osobę fizyczną występującą z wnioskiem bez konieczności fizycznej obecności w jednym $z$ wybranych punktów potwierdzających. Osoba fizyczna występująca z wnioskiem o potwierdzenie profilu zaufanego ePUAP, jak również przedłużenie jego ważności albo unieważnienie, może dokonać tego samodzielnie przy nieodpłatnym wykorzystaniu środka identyfikacji elektronicznej stosowanego do uwierzytelniania w systemie teleinformatycznym banku krajowego lub innego przedsiębiorcy spełniającego warunki, o których mowa w art. 20a ust. 3 pkt 2 u.i.d. Oznacza to, że osoba fizyczna, która pragnie dysponować podpisem potwierdzonym profilem zaufanym ePUAP, będzie mogła nabyć te uprawnienia bez konieczności wychodzenia z domu, przy wykorzystaniu dość powszechnie stosowanych kodów autoryzacyjnych udostępnianych w usługach bankowości mobilnej. Po prawidłowym przeprowadzeniu owej procedury, zgodnie $\mathrm{z}$ art. 20b ust. 1 u.i.d. w 3-letnim okresie ważności owego profilu można uwierzytelniać składane przez użytkownika oświadczenia przy wykorzystaniu podpisu potwierdzonego profilem zaufanym ePUAP. Natomiast dane w postaci elektronicznej opatrzone takim podpisem są równoważne pod względem skutków prawnych dokumentowi opatrzonemu podpisem 
własnoręcznym, chyba że przepisy odrębne stanowią inaczej, choć w tym zakresie trzeba od razu wskazać, że przepisy u.o.z.e. nie modyfikują tej generalnej zasady. Ze względu na nowość wprowadzanych rozwiązań samodzielne potwierdzenie omawianego profilu jest możliwe przy wykorzystaniu systemów teleinformatycznych m.in. PKO Banku Polskiego S.A., Inteligo Financial Services S.A., Bank Polska Kasa Opieki S.A. czy Bank Millennium S.A. Dalszy rozwój tego instrumentu, angażujący w tę współpracę także inne banki wykorzystujące systemy bankowości mobilnej, przesądzi o powszechności tej metody potwierdzania profilu zaufanego ePUAP, a w związku z tym także o popularności wykorzystywania podpisów potwierdzonych profilem zaufanym ePUAP przez osoby fizyczne reprezentujące m.in. podmioty uczestniczące $\mathrm{w}$ aukcjach OZE. W związku z powyższym kluczowym elementem oferty aukcyjnej, oprócz szczegółowego wypełnienia formularza dostępnego w systemie IPA, w tym przede wszystkim oferowanej ceny oraz wolumenu energii elektrycznej z OZE, będzie konieczność posiadania oraz wykorzystania jednej z dwóch opisanych form podpisu elektronicznego.

\section{Podsumowanie}

Reasumując, a jednocześnie porównując obie formy podpisów umożliwiających skuteczne złożenie oferty w aukcji OZE, należy wskazać, że wiele zalet przemawia na korzyść wykorzystania podpisu potwierdzonego profilem zaufanym ePUAP. Niezależnie od uproszczeń natury formalnej, w tym zwłaszcza rozwijającej się możliwości samodzielnego potwierdzania owego profilu, wykorzystywanie tego podpisu jest całkowicie darmowe, a więc stanowi przykład jednej z nowoczesnych usług oferowanych przez administrację publiczną społeczeństwu, które na coraz większą skalę wykorzystuje narzędzia teleinformatyczne. Wytwórcy będący osobami fizycznymi albo podmiotami reprezentującymi osobę prawną w łatwy i darmowy sposób będą zatem mogli uzyskać jeden $z$ dwóch rodzajów podpisu elektronicznego umożliwiający im skuteczne wniesienie oferty na aukcji OZE, a także uzyskać instrument prawny pozwalający załatwiać inne sprawy administracyjne $\mathrm{w}$ formie elektronicznej. Natomiast znana już na polskim rynku usługa polegająca na świadczeniu usług zaufania związanych z udostępnieniem kwalifikowanego podpisu elektronicznego, tak jak dotychczas, najprawdopodobniej będzie usługą komercyjną, za której świadczenie pobierane są 
odpowiednie gratyfikacje finansowe. Niemniej zaletą kwalifikowanych podpisów elektronicznych jest możliwość wykorzystywania owego instrumentu uwierzytelniania składanych przez siebie oświadczeń na szerszą skalę niż tylko aukcje OZE, w tym także w kontaktach z innymi przedsiębiorcami z państw członkowskich UE, gdyż jak dotąd darmowy podpis potwierdzony profilem zaufanym ePUAP stosowany jest jedynie w kontaktach z administracją publiczną. Niezależnie od opisanych cech obie formy podpisów elektronicznych mogą być równolegle stosowane do podpisywania ofert składanych w aukcjach OZE.

Odnosząc się natomiast do systemu IPA jako platformy internetowej umożliwiającej przeprowadzanie aukcji OZE w środowisku internetowym, należy wskazać, że wiele funkcjonalności udostępnionych na tej platformie pozwala na skuteczne przejście wszystkich etapów przyznania pomocy publicznej na wytwarzanie energii z OZE. W tym zakresie można się jedynie zastanawiać, czy aukcje OZE nie powinny mieć bardziej dynamicznego charakteru przypominającego mechanizm aukcyjny. De lege ferenda z łatwością można wyobrazić sobie system internetowy, w którym uczestnik aukcji OZE widzi oferty innych uczestników i w czasie rzeczywistym reaguje na oferty innych wytwórców. W dynamicznym modelu aukcji konkurujący ze sobą wytwórcy mogliby składać kontroferty, a konkurowanie w poszczególnych aukcjach byłoby nie tylko bardziej efektywne, ale prowadziłoby również do wyboru rzeczywiście najtańszych ofert wytworzenia energii elektrycznej z OZE. W aktualnym stanie prawnym przepisy u.o.z.e. kształtujące zasady przeprowadzania aukcji OZE bardziej przypominają mechanizm przetargu, w którym to organizator według określonych kryteriów wybiera najkorzystniejszą ofertę $\mathrm{z}$ tych złożonych $\mathrm{w}$ okresie przeprowadzenia przetargu albo pozostawia go bez rozstrzygnięcia. Niezależnie od poczynionych powyżej zastrzeżeń podkreślenia wymaga również fakt, że wykorzystanie elektronicznych aukcji OZE, choć wymaga dalszego rozwoju usług zaufania $\mathrm{w}$ postaci podpisów elektronicznych, stanowi ważny krok w rozwoju innowacji w sferze e-administracji, w tym również po raz pierwszy w wysoce konkurencyjnym modelu udzielania pomocy publicznej na wytwarzanie energii elektrycznej z OZE. Internetowe aukcje OZE otwierają zatem nowy rozdział w zakresie gospodarczych relacji B2A (business-to-administration), przenosząc owe relacje również do środowiska internetowego, gdyż całe postępowanie aukcyjne w zakresie wyłonienia wytwórców objętych mechanizmami wsparcia finansowego prowadzone jest wyłącznie w internetowym systemie IPA. 


\section{SOME REMARKS ON THE INTERNET AUCTION PLATFORM WHICH IS A NEW SYSTEM OF SUPPORTING RENEWABLE ENERGY RESOURCES IN POLAND IN THE CONTEXT OF ELECTRONIC SIGNATURES}

\section{Sum mary}

The paper describes certain basic principles of the new system of supporting renewable energy sources (RES) introduced in Poland. The amended Polish Act on Renewable Energy Sources (Polish RES Act) has introduced an auction system which is a new legal instrument enabling the selection of RES generators with adequate financial support. Each Renewable Energy Sources project (RES plant project) to generate and sell electricity must go officially through an auction. The Internet Auction Platform is an IT tool used in the process. It enables to conduct the pre-qualification procedure as well as to prepare the auction offer. This new solution has entailed certain legal issues that must be addressed such as the access to the IT system, electronic submission of tenders or the use of an electronic signature to confirm the statements made in the electronic procedure. All these issues have been discussed in this paper. The paper also contains an analysis of the differences between two possible forms of electronic signature that may be used in the process, and identifies the main advantages and disadvantages of either. It is then concluded that although the online RES auction could be more competitive, in the version as it is it allows to carry out an effective auction.

Keywords: supporting renewable energy sources - internet RES auction - electronic signatures 